\title{
Sarcoid Reaction Observed in a Worker with a History of Asbestos Exposure
}

\author{
Masamitsu KIDO', Akira KAJIKI', Katsumi HIRAOKA' and A'kio HORIE ${ }^{2}$ \\ 'Division of Respiratory Disease, School of Medicine, University of Occupational and Environmenal Health, \\ Japan. Kitakyushu 807, Japan \\ ${ }^{2}$ Department of Pathology and Oncology, School of Medicine, University of Occupational and Environmental Health, \\ Japan. Kitakyushu 807, Japan
}

Abstract: $\quad$ Bilateral hilar and mediastinal lymphadenopathy was observed in a 32-year-old man who had been engaged in asbestos spraying for 16 years. Lymph nodes obtained from Daniel's biopsy revealed tissue reaction compatible with sarcoidosis. On the other hand, a large number of asbestos particles were detected in the lung tissue from transbronchial lung biopsy and in bronchoalveolar lavage fluid, but no epithelioid granuloma was observed in the lung tissue. Various immunoserological findings such as PPD skin test, serum angiotensin converting enzyme activity, serum $\beta$-glucuronidase and lysozyme level, serum antinuclear antibody, lymphocyte subset of blood and bronchoalveolar lavage fluid were inconsistent with sarcoidosis. However, lymph node enlargement and immunological abnormalities in this patient may be related to asbestos exposure and may not have occurred merely by chance.

Key words: bilateral hilar lymphadenopathy, sarcoid reaction, asbestos, transbronchial lung biopsy, bronchoalveolar lavage.

(Received 15 March 1990, accepted 21 June 1990)

\section{Introduction}

Pulmonary fibrosis, pleural thickening, lung cancer and pleural mesothelioma are wellknown respiratory disorders caused by asbestos (American Thoracic Society, 1986). However, there have been no reports of sarcoid reaction associated with asbestos exposure.

We noted sarcoid reaction in lymph nodes of a worker with a history of severe asbestos exposure and discuss the relationship between asbestos exposure and sarcoid reaction.

\section{Case Report}

This 32-year-old furnace builder had undergone regular examinations twice a year, and was referred to our clinic when bilateral hilar lymphadenopathy (BHL) was noted by the latest examination. He had been engaged in asbestos spraying in the fire-proof construction of furnaces since the age of 16 years. He also had a 14-year history of smoking 30 cigarettes per day.

On physical examination, lymph nodes were palpated in the bilateral neck regions, and piping rales were auscultated in the bilateral lungs. 
General laboratory examination yielded no abnormal findings (Table 1). PPD skin test was strongly positive, and serum angiotensin converting enzyme, lysozyme, and $\beta$-glucuronidase levels were all within normal range. Antinuclear antibody was positive at $\times 20$ and showed a diffuse pattern, and anti-DNA antibody was negative. Among the immunoglobulins, $\operatorname{IgG}$, $\operatorname{IgA}$, and $\operatorname{IgM}$ were normal, but $\operatorname{IgE}$ was high, 3,850 IU/ml. Tumor markers such as CEA, CA19-9, SLX and SCG were all within normal range.

Regarding pulmonary function studies (Table 2), the forced expiratory volume in one second $\left(\mathrm{FEV}_{\llcorner .0}\right)$ and its ratio to forced vital capacity $\left(\mathrm{FEV}_{1.0} / \mathrm{FVG}_{\mathrm{C}}\right.$ ) were slightly reduced, expiratory flow at $50 \%$ and $25 \%$ FVC were significantly reduced, the ratio of closing volume to vital capacity $(\mathrm{CV} / \mathrm{VC} \%)$ was increased, and alveolar-arterial $\mathrm{PO}_{2}$ difference $(\mathrm{A}$ $\mathrm{aDO}_{2}$ ) was increased, showing a pattern of small airway dysfunction.

Ophthalmological examination revealed no abnormal findings.

Figure 1 shows the chest roentgenogram obtained at the initial examination. In addition to typical BHL, mild reticular and nodular opacities were observed in the bilateral middle to lower lungs. These changes had been present at least for one year. Reticulo-

Table 1. Laboratory data

ESR $5 \mathrm{~mm} / \mathrm{hr}, \mathrm{CRP}(-)$, Cold Agglutination Test $128 \times$
PPD skin test: $19 \times 16 / 75 \times 42$
ACE: 18.6 IU $(8.3-21.4)$
Serum lysozyme: $9.8 \mu \mathrm{g} / \mathrm{ml}(5.0-10.0)$
$\beta$-glucuronidase: $950 \mu \mathrm{g} / \mathrm{dl} / \mathrm{hr}(500-1,700)$
ANA (+) diffuse pattern $20 \times$
Anti DNA-Ab $<5.0 \mathrm{U} / \mathrm{ml}, \mathrm{Anti} \mathrm{SM-Ab}<1 \times$
IgG $1,570 \mathrm{mg} / \mathrm{dl}, \mathrm{IgA} 238 \mathrm{mg} / \mathrm{dl}, \mathrm{IgM} 154 \mathrm{mg} / \mathrm{dl}$
$\mathrm{IgE} 3,850.0 \mathrm{U}, \mathrm{C}_{3} 62, \mathrm{C}_{4} 21, \mathrm{CH} \mathrm{H}_{50} 40$
CEA $1.4 \mathrm{ng} / \mathrm{ml}(<2.5), \mathrm{SCC}<1.5 \mathrm{ng} / \mathrm{ml}(<1.5)$

Value in parenthesis shows normal range.

Table 2. Pulmonary function tests

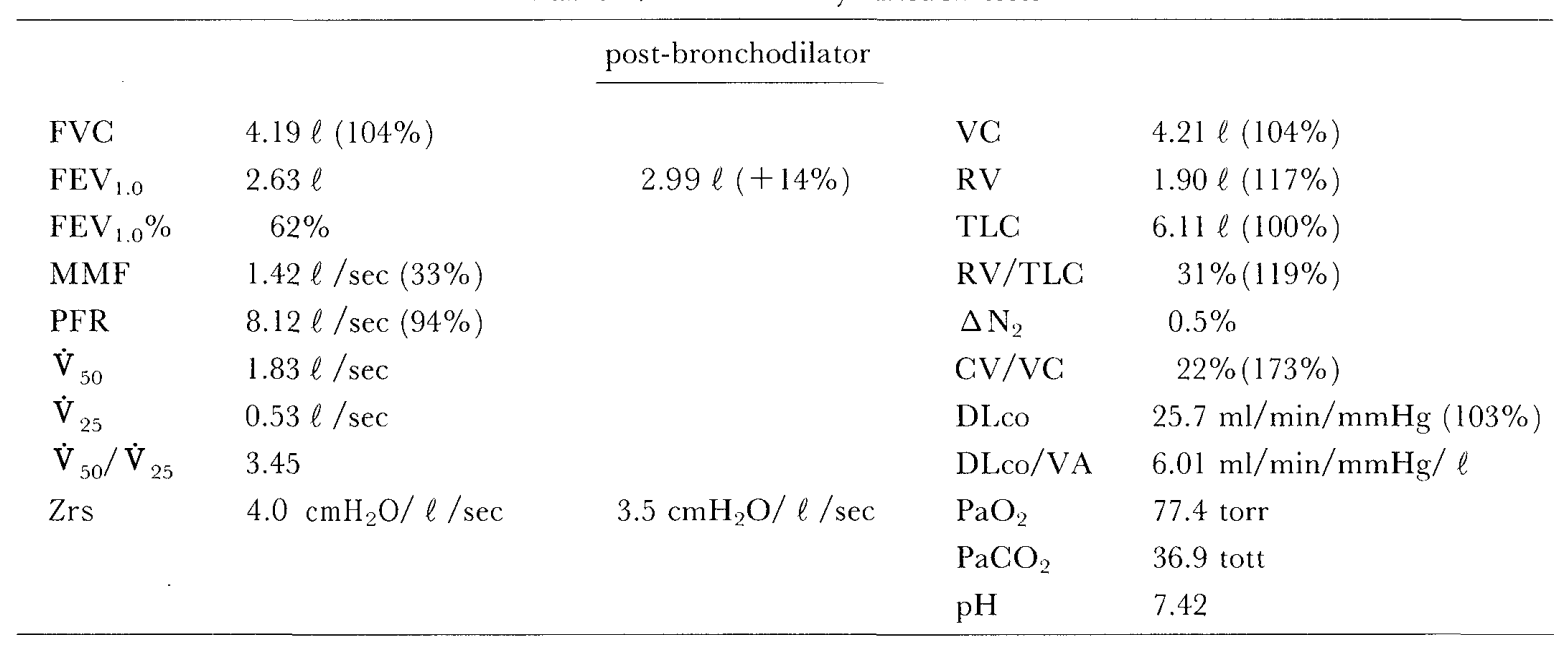


nodular opacities in the lung were evident also by high-resolution CT. Uptake of ${ }^{67} \mathrm{Ga}$ was high in the hilar lymph nodes.

Bronchofiberscopy showed no abnormal findings in the vocal cord, trachea and carina except for occasional mild capillary dilatation in right $\mathrm{B}^{1}\left(\mathrm{rB}^{1}\right)$ and $\mathrm{rB}^{2}$. Histopathological

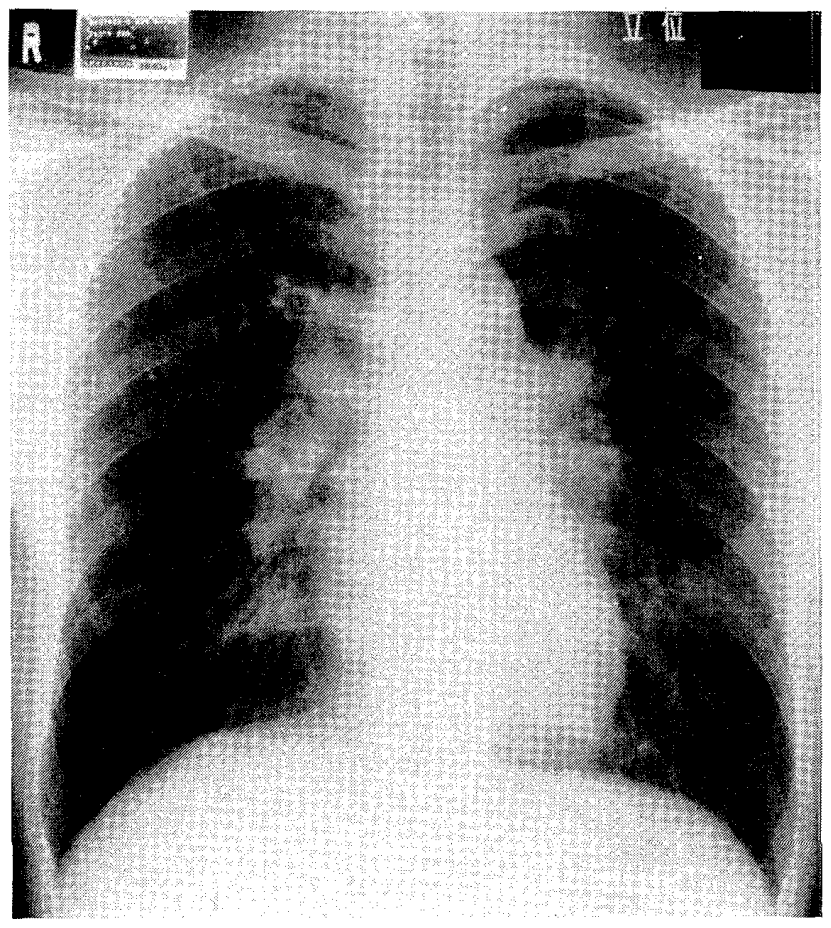

Fig. 1. Chest radiograph shows bilateral hilar lymph node enlargement and diffuse reticulonodular opacities, especially in the bilateral middle and lower lungs.

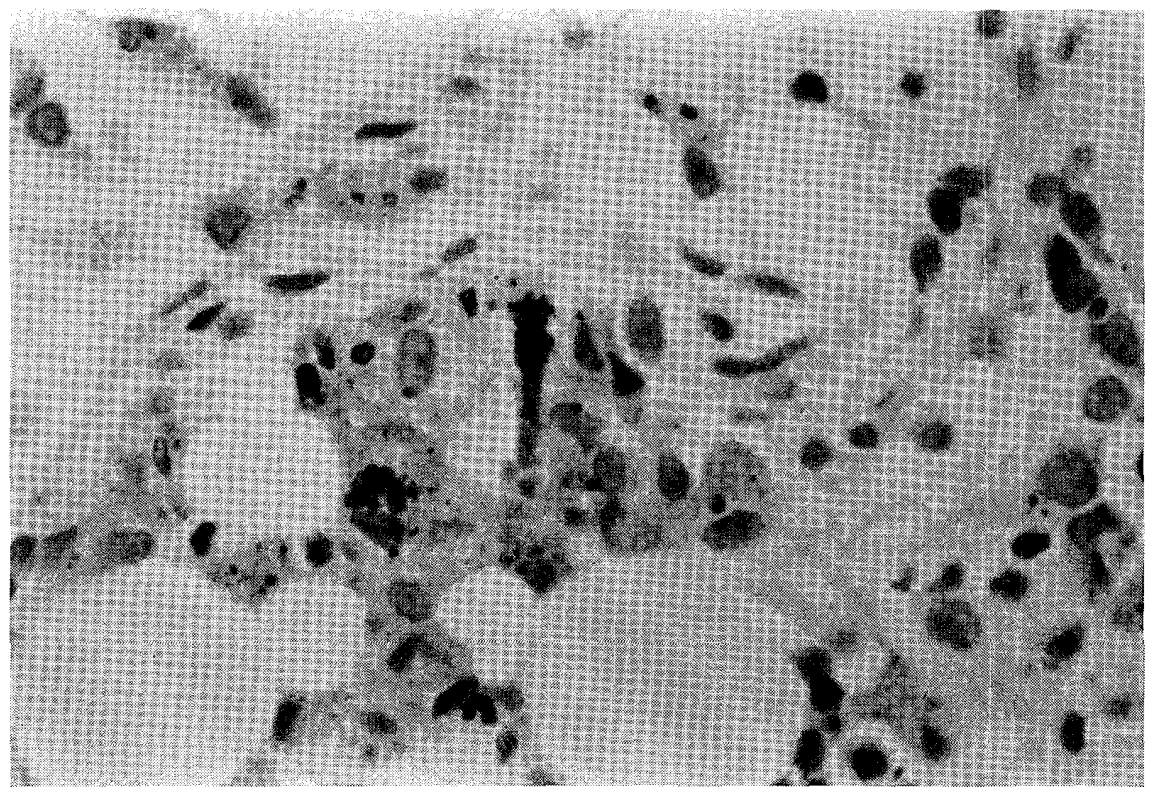

Fig. 2. Transbronchial biopsy specimen of the lung stained by hematoxilin-eosin shows no epitheloid cells but ferruginous bodies are scattered with depositions of carbon particles $(\times 100)$. 
specimens, derived from transbronchial lung biopsy (TBLB) at $\mathrm{rB}^{8} \mathrm{a}$ and $\mathrm{rB}^{9} \mathrm{a}$ showed no signs of epithelioid granuloma (Fig. 2), but a thickening of the pulmonary alveolar septa and ferruginous asbestos bodies were observed. Bronchoalveolar lavage fluid (BALF), obtained simultaneously, also contained 88 asbestos bodies per milliliter (Fig. 3).

Alveolar macrophages were dominant in the cell population of BALF, and lymphocytes accounted for $2.5 \%$. Among lymphocyte subsets, however, CD8 ${ }^{+}$increased and CD4 ${ }^{+} /$ $\mathrm{CD}^{+}$decreased, which is incompatible with sarcoidosis (Table 3).

As shown in Fig. 4, a specimen from Daniel's biopsy revealed a sarcoid-like granuloma, namely an aggregation of epithelioid cells and giant cells. However, typical asteroid bodies were not observed in these giant cells. Deposition of carbon particles was prominent for the age of the patient.

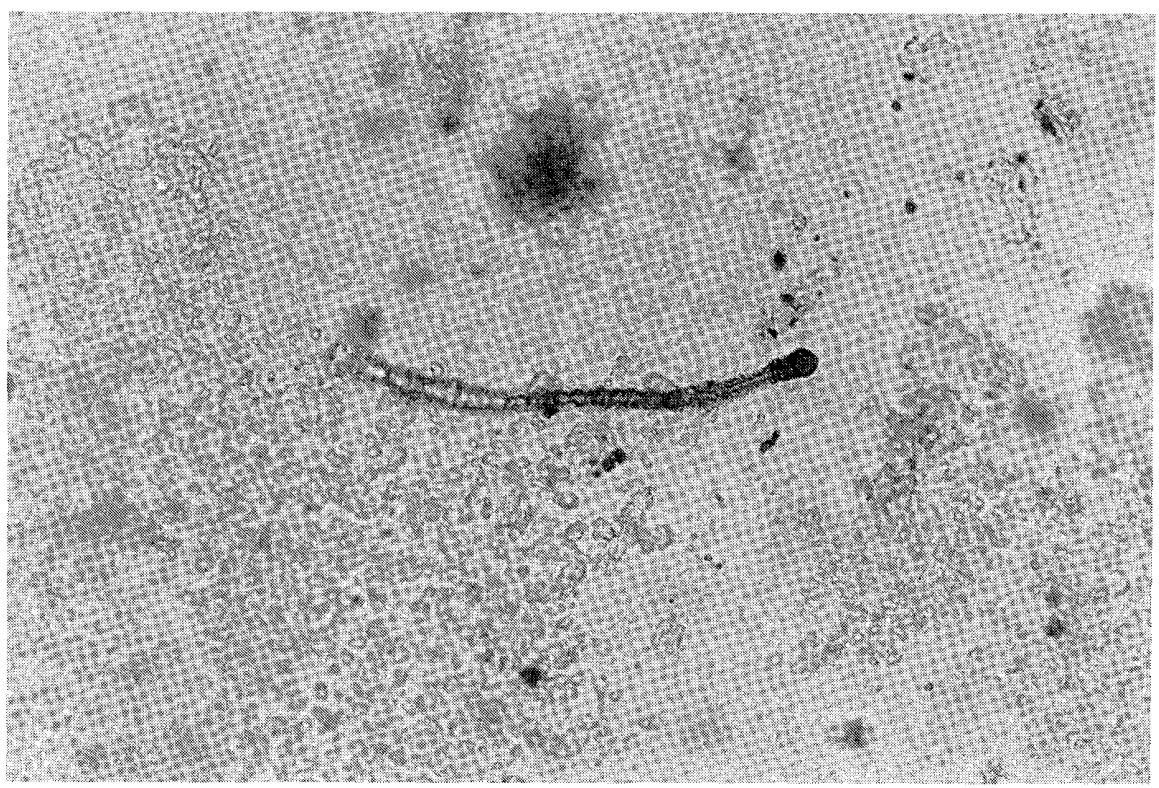

Fig. 3. Ferruginous bodies in the BALF $(\times 400)$.

Table 3. Analysis of bronchoalveolar lavage fluid

\begin{tabular}{|c|c|c|}
\hline \multicolumn{3}{|c|}{ Total cells $20.8 \times 10^{6}\left(28.2 \times 10^{4} / \mathrm{ml}\right)$} \\
\hline \multicolumn{2}{|c|}{ Differential count } & $(\%)$ \\
\hline & Macrophage & $90.0 \%$ \\
\hline & Lymphocyte & $2.5 \%$ \\
\hline & Neutrophil & $1.7 \%$ \\
\hline & Eosinophil & $5.8 \%$ \\
\hline & Basophil & $0 \%$ \\
\hline & BAL & PBL \\
\hline $\mathrm{CD}^{+}$ & $85.8 \%$ & $65.4 \%$ \\
\hline $\mathrm{CD} 4^{+}$ & $46.3 \%$ & $46.1 \%$ \\
\hline $\mathrm{CD}^{+}$ & $52.6 \%$ & $22.2 \%$ \\
\hline $\mathrm{CD} 4^{+} / \mathrm{CD} 8^{+}$ & 0.88 & 2.08 \\
\hline
\end{tabular}




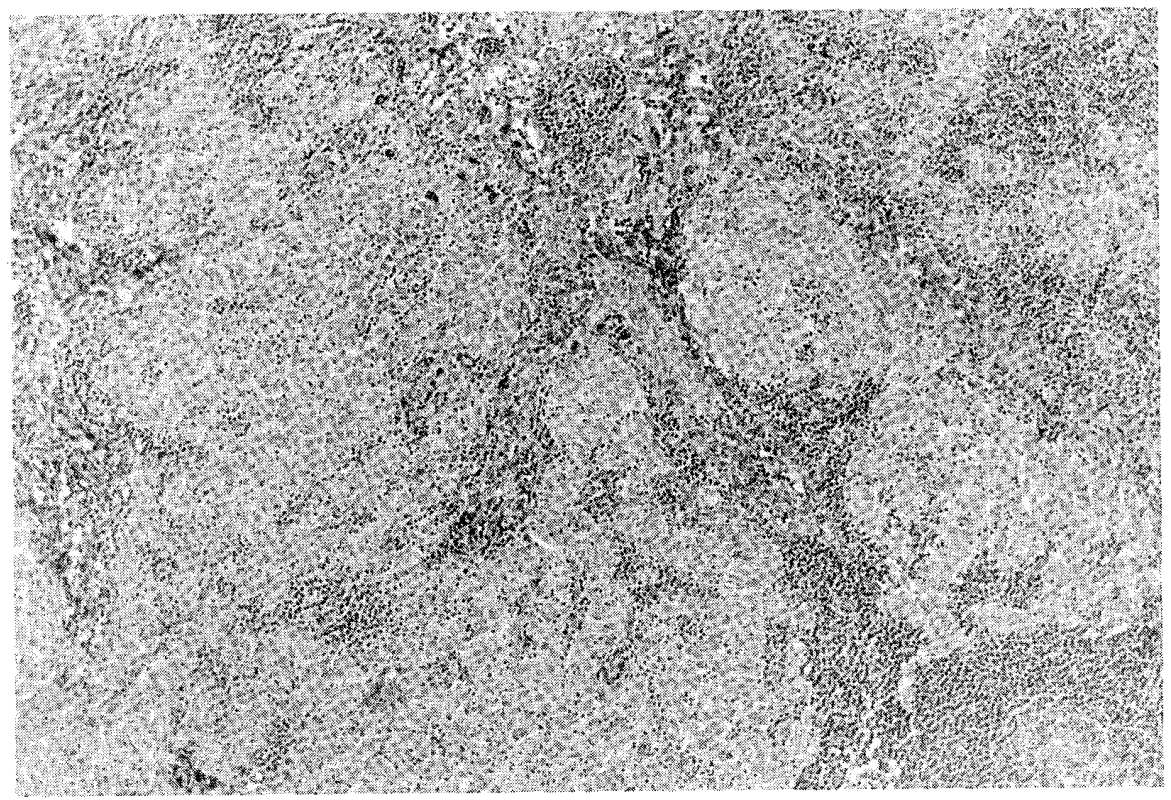

Fig. 4. Specimen of Daniel's biopsy shows noncaseating granuloma composed of epithelioid cells and giant cells. No asterid bodies can be observed. Numerous Fe-positive granules are observed mainly in the histiocytes with sarcoid reaction in the lymph node sinus. Deposition of carbon particles is conspicuous at this patient's age $(\times 40)$.

\section{Discussion}

BHL was observed in a 32-year-old man who had been engaged in asbestos spraying for 16 years. Chest radiogram and CT revealed pulmonary hilar and mediastinal lymph nodes enlargement with mild interstitial changes of the lung, which is consistent with sarcoidosis. Biopsy specimen obtained from the right cervical lymph nodes revealed epithelioid cell reaction which is also compatible with sarcoidosis. On the other hand, a large number of asbestos bodies were detected in the lung tissue obtained from TBLB. Numerous asbestos bodies were also found in BALF, but no epithelioid granuloma was observed in the lung tissues. Various immunoserological examinations including PPD skin test, serum angiotensin converting enzyme activity, serum $\beta$-glucuronidase, lysozyme level, serum antinuclear antibody were inconsistent with sarcoidosis. BALF contained predominantly alveolar macrophages and lymphocyte subset revealed increased CD8 ${ }^{+}$. These results suggest autoimmune reaction rather than sarcoidosis or simple asbestosis (Costabel et al., 1987; Kang et al., 1974).

To our knowledge, only one autopsy case has been reported in which sarcoid-like pulmonary lesion was observed in close relation to asbestosis (Tayot et al., 1976). They discussed the histogenesis of the lesion but gave no clinical data relevant to consider the mechanism of these patholgical changes.

Although various immunoserological changes were not necessarily consistent with sarcoidosis, lymph node enlargement and immunological abnormalities in our patient may be 
related to asbestos exposure and not have occurred merely by chance (Turner-Warwick \& Parkes, 1970). There is now increasing evidence that asbestos exposure induces immunological reactions in the lung. Further studies will be needed to determine this relationship.

\section{References}

American Thoracic Society (1986): Statement on diagnosis of nonmalignant diseases related to asbestos. Am. Rev. Respir. Dis., 134: 363-368.

Costabel, U., Bross, K. J., Huck, E. et al. (1987): Lung and blood lymphocyte subsets in asbestosis and in mixed dust pneumoconiosis. Chest, 91: 110-112.

Kang, K. Y., Sera, Y., Okochi, T. et al. (1974): T lymphocytes in asbestosis. New Engl. J. Med., 291: $735-736$.

Turner-Warwick, M. \& Parkes, W. R. (1970): Circulating rheumatoid and antinuclear factors in asbestos workers. Br. Med. J., 3: 492-495.

Tayot, J., Henin-Landes, D., Fondimare, A. et al. (1976): Asbestose avec lésions pulmonaires "sarcoidlike". A propos d'une observation anatomo-clinique. Ann. Anat. Pathol., 21: 269-276.

\section{アスベスト曝露労働者にみられたサルコイド反応の1例}

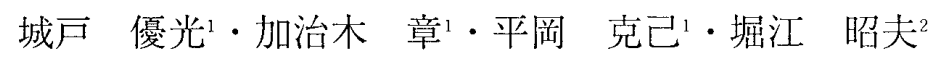

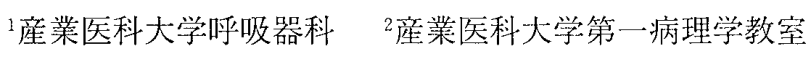

要 旨： 16 年間アスベストの吹き付け作業に従事していた 32 才の男性に両側肺門および縦隔の リンパ節腫大がみられ，頸部リンパ節の生検によりサルコイド様反応が明らかとなった。 経気管支肺生検および気管支肺胞洗浄により多数のアスベスト小体が検出されたが肺組織 にはサルコイドーシスを示唆する類上.皮肉芽腫はみられなかった．免疫血清学的にはッベ ルクリン反応は強陽性で, ACE, Lysozyme, $\beta$-gulucuronidase は共に正常範囲でサルコ イドーシスとは矛盾する所見を示した。抗核抗体は陽性， IgE は高值を示し，肺胞洗浄液 のリンパ球は $\mathrm{CD}^{+}$優位であった. 現在までの文献的検索では，アスベストによるサル コイド反応の報告はないが，これらの反応は単なる偶然ではなく，アスべスト曝露により 惹起された可能性が考えられる.

J. UOEH（産業医大誌），12( 3 ): 355-360 (1990) 